\title{
Activation of the CED3/ICE-Related Protease CPP32 in Cerebellar Granule Neurons Undergoing Apoptosis But Not Necrosis
}

\author{
Robert C. Armstrong, ${ }^{1}$ Teresa J. Aja, ${ }^{1}$ Kim D. Hoang, ${ }^{1}$ Smita Gaur, ${ }^{1}$ Xu Bai, ${ }^{1}$ Emad S. Alnemri, ${ }^{2}$ \\ Gerald Litwack, ${ }^{2}$ Donald S. Karanewsky, ${ }^{1}$ Lawrence C. Fritz, ${ }^{1}$ and Kevin J. Tomaselli ${ }^{1}$ \\ 1/DUN Pharmaceuticals, Inc., La Jolla, California 92037, and 2Jefferson Cancer Institute, Thomas Jefferson University, \\ Philadelphia, Pennsylvania 19107
}

\begin{abstract}
Neuronal apoptosis occurs during nervous system development and after pathological insults to the adult nervous system. Inhibition of CED3/ICE-related proteases has been shown to inhibit neuronal apoptosis in vitro and in vivo, indicating a role for these cysteine proteases in neuronal apoptosis. We have studied the activation of the CED3/ICE-related protease CPP32 in two in vitro models of mouse cerebellar granule neuronal cell death: $\mathrm{K}^{+}$/serum deprivation-induced apoptosis and glutamate-induced necrosis. Pretreatment of granule neurons with a selective, irreversible inhibitor of CED3/ICE family proteases, ZVAD-fluoromethylketone, specifically inhibited granule neuron apoptosis but not necrosis, indicating a selective role for CED3/ICE proteases in granule neuron apoptosis. Extracts prepared from apoptotic, but not necrotic, granule neurons contained a protease activity that cleaved the CPP32 substrate Ac-DEVD-aminomethylcoumarin. Induction of the protease activity was prevented by inhibitors of RNA or protein synthesis or by the CED3/ICE protease inhibitor. Affinity labeling of the protease activity with an irreversible CED3/ICE protease inhib-
\end{abstract}

itor, ZVK(biotin)D-fluoromethylketone, identified two putative protease subunits, p20 and p18, that were present in apoptotic but not necrotic granule neuron extracts. Western blotting with antibodies to the $C$ terminus of the large subunit of mouse CPP32 (anti-CPP32) identified p20 and p18 as processed subunits of the CPP32 proenzyme. Anti-CPP32 specifically inhibited the DEVD-amc cleaving activity, verifying the presence of active CPP32 protease in the apoptotic granule neuron extracts. Western blotting demonstrated that the CPP32 proenzyme was expressed in granule neurons before induction of apoptosis. These results demonstrate that the CED3/ICE homolog CPP32 is processed and activated during cerebellar granule neuron apoptosis. CPP32 activation requires macromolecular synthesis and CED3/ICE protease activity. The lack of CPP32 activation during granule neuron necrosis suggests that proteolytic processing and activation of CED3/ICE proteases are specific biochemical markers of apoptosis.

Key words: apoptosis; necrosis; cerebellar neurons; CED3/ ICE proteases; CPP32; Caspase
Cell death is a prominent feature of the developing nervous system. In both neuronal and glial populations, as many as $70 \%$ of the cells that are generated die during a period of naturally occurring cell death (for review, see Oppenheim, 1991; Raff et al., 1993). Many naturally occurring neuronal cell deaths are apoptotic in nature (Oppenheim et al., 1990; Wood et al., 1993; Blaschke et al., 1996) and can be modeled in vitro by trophic factor deprivation. For example, developing superior cervical ganglion neurons undergo apoptosis when deprived of nerve growth factor in vitro (Martin et al., 1988; Deckwerth and Johnson, 1993). Similarly, spinal motoneurons undergo apoptosis in culture when deprived of muscle-derived survival factors (Milligan et al., 1994). Neuronal cell death induced by trophic factor deprivation is blocked, in some instances, by expression of the anti-apoptotic human proto-oncogene $b c l$-2 (Allsopp et al., 1993).

In the adult nervous system, neuronal cell death occurs in response to ischemia. Recent studies provide evidence for both apoptotic and necrotic neuronal cell death after ischemia (for review, see Bredesen, 1995). For example, inhibition of macromolecular synthesis or transgenic overexpression of $\mathrm{Bcl}-2$ protein

\footnotetext{
Received Sept. 4, 1996; revised Oct. 17, 1996; accepted Oct. 23, 1996.

We thank Drs. Anu Srinivasan and Yan Wang for helpful discussions and Lisa Trout for administrative assistance.

Correspondence should be addressed to Kevin J. Tomaselli, Cell Biology, IDUN Pharmaceuticals, Inc., 11085 North Torrey Pines Road, Suite 300, La Jolla, CA 92037.

Copyright (C) 1997 Society for Neuroscience $0270-6474 / 97 / 170553-10 \$ 05.00 / 0$
}

in neurons reduces infarct size in rodent models of brain ischemia (Linnik et al., 1993; Martinou et al., 1994). Thus, in addition to programmed neuronal cell death during development, neuronal apoptosis occurs in the adult nervous system in response to injury.

Genetic studies in the roundworm Caenorhabditis elegans identified the ced3 gene, whose function is required for all of the developmentally programmed deaths in the hermaphrodite (Yuan et al., 1993). CED3 is a cysteine protease that cleaves proteins at Asp-X peptide bonds (Xue and Horvitz, 1995; Hugunin et al., 1996; Xue et al., 1996). There are currently ten human homologs of CED3 comprising the CED3/ICE family of cysteine proteases (Ceretti et al., 1992; Thornberry et al., 1992; Kumar et al., 1993; Fernandes-Alnemri et al., 1994, 1995a,b, 1996; Wang et al., 1994; Faucheu et al., 1995; Kamens et al., 1995; Munday et al., 1995; Boldin et al., 1996; Duan et al., 1996; Muzio et al., 1996; Srinivasula et al., 1996). As with CED3, all of the mammalian CED3/ICE proteases identified to date are cysteine proteases with Asp cleavage specificities. Several studies have implicated CED3/ICE proteases in neuronal apoptosis. First, neuronal apoptosis can be blocked by expression of either of two viral anti-apoptotic genes, CrmA or p35 (Rabizabeh et al., 1993; Gagliardini et al., 1994), whose protein products are potent inhibitors of CED3/ICE proteases (Ray et al., 1992; Komiyama et al., 1994; Bump et al., 1995; Xue and Horvitz, 1995; Bertin et al., 1996). Second, selective peptide inhibitors of CED3/ICE proteases block apoptosis of lumbar spinal motoneurons, both in vitro and in vivo (Milligan et 
al., 1995). Because the viral and peptidyl inhibitors inhibit multiple CED3/ICE family members (Bump et al., 1995; Bertin et al., 1996), the protease targets of these inhibitors in neuronal cells are currently unknown. Although mRNAs encoding CED3/ICE proteases have been detected in brain (Kumar et al., 1993; Wang et al., 1994; Fernandes-Alnemri et al., 1995b; 1996), no studies have addressed the functions of specific family members in neuronal apoptosis.

Recent evidence has implicated the CED3/ICE-related protease CPP32 in the effector pathway of apoptosis in non-neuronal cells (Darmon et al., 1995; Nicholson et al., 1995; Tewari et al., 1995). Consistent with such a role, CPP32 and a closely related homolog, MCH3/ICELAP3, are cleaved from their proenzyme forms and activated early during apoptosis by treatment with Fas antibody or staurosporine (Armstrong et al., 1996; Chinnaiyan et al., 1996; Duan et al., 1996; Schlegel et al., 1996). In the present study, we sought evidence of activation of CED3/ICE proteases in an in vitro model of cerebellar granule neuronal apoptosis (D'Mello et al., 1993; Yan et al., 1994; Galli et al., 1995). We demonstrate that CPP32 is cleaved and activated early during cerebellar granule neuron apoptosis. CPP32 activation was prevented when apoptosis was blocked by inhibitors of RNA or protein synthesis, or by a selective inhibitor of CED3/ICE proteases. In addition, CPP32 activation seemed to be specific for apoptosis, because it was not observed when cerebellar granule neurons underwent necrotic cell death.

\section{MATERIALS AND METHODS}

Neuronal cell culture. Cerebellar granule neurons were isolated from 3- to 4-d-old C57Black6 mice (Harlan Sprague Dawley, Indianapolis, IN) and were purified by density sedimentation. Briefly, cerebella were removed and dissociated with $0.25 \%$ trypsin (Worthington, Freehold, NJ) in calcium- and magnesium-free HBSS (BioWhittaker, Walkersville, MD) for $25 \mathrm{~min}$ at $37^{\circ} \mathrm{C}$. Trypsin was inactivated with an equal volume of Eagle's basal media (BME; Life Technologies, Gaithersburg, MD) containing $10 \%$ fetal bovine serum (Hyclone, Logan, UT) and $0.4 \%$ DNase (Worthington) before dissociation by trituration using a Pasteur pipette. Dissociated cells were centrifuged for $10 \mathrm{~min}$ at $3000 \mathrm{rpm}$ through a discontinuous percoll gradient $(35 \% / 60 \%)$. The granule neurons were harvested from the $35 \% / 60 \%$ interface and washed with calcium- and magnesium-free DPBS (BioWhittaker). The neurons were plated on poly-D-lysine-coated (Becton Dickinson, Bedford, MA) 96-well plates, 60 mM dishes, or eight-well chamber slides in BME supplemented with $10 \%$ fetal bovine serum, $25 \mathrm{~mm} \mathrm{KCl}$, and $50 \mu \mathrm{g} / \mathrm{ml}$ gentamicin sulfate at a density of 312,500 cells $/ \mathrm{cm}^{2}$. After the addition of $5 \mu \mathrm{M} \mathrm{AraC}$ on the second day, the cultures were maintained at $37^{\circ} \mathrm{C} / 5 \% \mathrm{CO}_{2}$ for $7 \mathrm{~d}$ without a change in medium.

Viability studies. After 7 d, apoptosis was induced (D'Mello et al., 1993) by switching to a medium containing reduced potassium and no serum. The medium change involved three sequential 5:1 dilutions with BME supplemented only with $5 \mathrm{~mm} \mathrm{KCl}$. To induce necrosis (Ankarcrona et al., 1995), cultures were exposed to $300 \mu \mathrm{M}$ or $3.0 \mathrm{~mm}$ glutamate for $30 \mathrm{~min}$ in Locke solution (134 mM NaCl, $25 \mathrm{~mm} \mathrm{KCl,} 4 \mathrm{~mm} \mathrm{NaHCO}, 5 \mathrm{~mm}$ HEPES, $2.3 \mathrm{~mm} \mathrm{CaCl}_{2}$, and $5 \mathrm{mM}$ glucose) in the presence of $10 \mu \mathrm{M}$ glycine. At the end of $30 \mathrm{~min}$, the cultures were washed in BME and returned to the original conditioned medium. Alternatively, necrosis was induced by a single media change to BME containing fresh serum. Exposure of $7 \mathrm{~d}$ cultured cerebellar granule neurons to fresh serum has been reported to induce an acute, NMDA receptor-dependent cell death (Schramm et al., 1990). The addition of inhibitors or other compounds was carried out concomitantly with treatment. Viability was measured in triplicate in 96-well plates by either monitoring the conversion of Alamar blue to a fluorescent product or by quantitative colorimetric assay with 3-(4,5-dimethylthiazol-2-yl)-2,5-diphenyltetrazolium bromide (MTT). Viability was expressed as the ratio of the signal obtained from treated cultures and the signal from untouched control cultures multiplied by 100 (percentage control).

Assessment of nuclear morphology. Eight-well chamber slides were treated as described above. Cells were labeled with Hoechst 33342 (5 $\mu \mathrm{g} / \mathrm{ml}$ ) for $15 \mathrm{~min}$, washed in PBS, and fixed in $10 \%$ formalin. Fixed cells were washed and mounted under glass coverslips with citifluor and viewed on a Nikon Diaphot microscope with illumination at $430 \mathrm{~nm}$ ultraviolet light.

DEVD-amc cleavage studies. Cells in 96-well plates were treated as described above. At the appropriate time, medium was aspirated, and the neurons were lysed in $50 \mu \mathrm{l}$ of buffer A (10 mM HEPES, pH 7.4, $42 \mathrm{~mm}$ $\mathrm{KCl}, 5 \mathrm{mM} \mathrm{MgCl}_{2}, 1 \mathrm{~mm}$ PMSF, $0.1 \mathrm{~mm}$ EDTA, $0.1 \mathrm{~mm}$ EGTA, $1 \mathrm{~mm}$ DTT, $1 \mu \mathrm{g} / \mathrm{ml}$ pepstatin A, $1 \mu \mathrm{g} / \mathrm{ml}$ leupeptin, $5 \mu \mathrm{g} / \mathrm{ml}$ aprotinin, $0.5 \%$ CHAPS). DEVD-amc was added to a final concentration of $10 \mu \mathrm{M}$ in 150 $\mu l$ of buffer B (25 mM HEPES, 1 mM EDTA, $0.1 \%$ CHAPS, $10 \%$ sucrose, $3 \mathrm{~mm}$ DTT, $\mathrm{pH}$ 7.5). Fluorescent amc production was measured at excitation $360 \mathrm{~nm}$, emission $460 \mathrm{~nm}$, using a Cytofluor II fluorescent plate reader (Millipore, Bedford, MA). Experiments were performed in triplicate, and the activity was expressed as change in fluorescence units per hour per 100,000 cells. For experiments examining the ability of ZVADfmk to inhibit the induction of DEVD-amc cleaving activity, neurons were washed four times with $200 \mu \mathrm{l}$ PBS to remove residual inhibitor before cell lysis. To ensure that excess inhibitor was removed by this washing protocol, recombinant human CPP32 was added to control cell lysates that either had been exposed or not been exposed to ZVAD-fmk, and added CPP32 activity was compared with CPP32 alone.

Titration experiments using Ac-DEVD-aldehyde and anti-CPP32 antibody were performed against neuronal extracts derived from $60 \mathrm{~mm}$ plates $8 \mathrm{hr}$ after $\mathrm{K}^{+}$switching. For these experiments, plates with $5 \times 10^{6}$ neurons were harvested by scraping in PBS and centrifuging at $5000 \times g$ for $15 \mathrm{~min}$. Cells were lysed in $40 \mu \mathrm{l}$ of buffer $\mathrm{A}$, and extracts were assayed for DEVD-amc cleaving activity. Equivalent units of neuronal extract, recombinant human CPP32, and mouse ICE proteases were then used to titrate the activity of the anti-CPP32. Recombinant CPP32 and ICE were expressed in Escherichia coli as described previously (Armstrong et al., 1996). The $8 \mathrm{hr}$ granule neuronal extract and CPP32 were tested with DEVD-amc as the substrate, whereas ICE was assayed with YVAD-amc as substrate. Experiments were performed in duplicate, and the results were expressed as the amount of residual activity when compared with the reaction with no inhibitor (percentage control).

$S D S-P A G E$ and Western blotting. SDS-PAGE was performed with precast gels from NOVEX (San Diego, CA) according to their specifications. Neuronal extracts were prepared by lysis in buffer A $(40 \mu \mathrm{l} / 5 \times$ $10^{6}$ cells). Twenty micrograms of extract were run in each lane and then transferred to nitrocellulose. Blots were blocked with 3\% BSA in TBST (50 mm Tris, $\mathrm{pH} 7.5,150 \mathrm{~mm} \mathrm{NaCl}, 0.05 \%$ Tween 20 ) and probed with 1:1000 dilutions of the anti-CPP32 antibodies in TBST/1\% BSA. Immunoreactive species were visualized with goat-anti-rabbit alkaline phosphatase-conjugated secondary antibody (Jackson Labs, Bar Harbor, ME). An antiserum (anti-CPP32p20Pep) was raised to a 13 amino acid peptide (CRGTELDCGIETD) corresponding to the $\mathrm{C}$ terminus of the p20 subunit of human and mouse CPP32. The peptide was coupled via cysteine to KLH. The antiserum was affinity-purified against the peptide coupled to Sepharose 4B (Pharmacia, Piscataway, NJ). The purified antiserum was shown by Western blotting to recognize the processed p20 subunit of recombinant, active mouse CPP32. A second antiserum (antiCPP32RP) was raised against the large subunit of recombinant human CPP32 purified from E. coli lysates by affinity chromotography (Srinivasula et al., 1996).

Affinity labeling with ZVK(biotin)D-fmk was achieved by incubation of $20 \mu \mathrm{g}$ of neuronal extract with $0.1 \mu \mathrm{M} \mathrm{ZVK}$ (biotin)D-fmk at $4^{\circ} \mathrm{C}$ for $20 \mathrm{hr}$, a time at which all of the DEVD-amc cleaving activity was inhibited. Labeled extracts were separated by SDS-PAGE and transferred to PVDF membrane, and biotinylated species were visualized with streptavidinconjugated alkaline phosphatase using a Tropix ECL kit (Bedford, MA).

Substrate and inhibitor synthesis. Ac-AspGluValAsp-amc (Ac-DEVDamc) was prepared by coupling $\mathrm{Ac}-\mathrm{Asp}\left(\mathrm{OBu}^{\mathrm{t}}\right)-\mathrm{OH}$ to $\mathrm{H}-\mathrm{Glu}\left(\mathrm{OBu}^{\mathrm{t}}\right)$ $\operatorname{ValAsp}\left(\mathrm{OBu}^{t}\right) \operatorname{ValAsp}\left(\mathrm{OBu}^{t}\right)$-amc followed by deprotection with $50 \%$ TFA in $\mathrm{CH}_{2} \mathrm{Cl}_{2}$. The requisite amine was prepared by coupling CBZX$\mathrm{Glu}\left(\mathrm{OBu}^{\mathrm{t}}\right) \mathrm{Val}-\mathrm{OH}$ to $\mathrm{H}-\mathrm{Asp}\left(\mathrm{OBu}^{\mathrm{t}}\right)$-amc followed by catalytic hydrogenation over Pd-C.

CBZ-ValLys(biotin)Asp- $\mathrm{CH}_{2} \mathrm{~F}$ [ZVK(biotin)D-fmk] was prepared via a modified Pfitzer-Moffatt oxidation of CBZ-ValLys(biotin) $\mathrm{NHCH}\left(\mathrm{CH}_{2}\right.$ $\left.\mathrm{CO}_{2} \mathrm{But}\right) \mathrm{CH}(\mathrm{OH}) \mathrm{CH}_{2} \mathrm{~F}$ with EDAC and pyridinium trifluoroacetate in DMSO- $\mathrm{CH}_{2} \mathrm{Cl}_{2}$ followed by deprotection with $35 \%$ TFA in $\mathrm{CH}_{2} \mathrm{Cl}_{2}$ / anisole. The requisite alcohol was prepared by coupling CBZValLys(biotin)- $\mathrm{OH}$ to $\mathrm{H}_{2} \mathrm{NCH}\left(\mathrm{CH}_{2} \mathrm{CO}_{2} \mathrm{Bu}^{\mathrm{t}}\right) \mathrm{CH}(\mathrm{OH}) \mathrm{CH}_{2} \mathrm{~F}$ (Revesz et al., 1994) with EDAC-HOBt in DMF. CBZ-ValLys(biotin)-OH was prepared in three steps from CBZ-ValLys(Boc)-OMe by successive reactions 
with (1) $25 \%$ TFA in $\mathrm{CH}_{2} \mathrm{Cl}_{2}$, (2) D-biotin-OSu in $\mathrm{CH}_{2} \mathrm{Cl}_{2}$-DMF, and (3) $1.0 \mathrm{~N} \mathrm{NaOH}$ in $\mathrm{MeOH}_{2} \mathrm{O}(4: 1)$.

Benzyloxycarbonyl-Val-Ala-Asp-fluoromethylketone (ZVAD-fmk) was synthesized as described in Armstrong et al. (1996). BenzyloxycarbonylPhe-Ala-fluoromethylketone (ZFA-fmk) was purchased from Enzyme Systems Products (Dublin, CA). Ac-Tyr-Val-Ala-Asp-amc (YVAD-amc) was purchased from Bachem (King of Prussia, PA).

\section{RESULTS}

\section{Induction of apoptosis and necrosis in cerebellar granule neurons}

Purified mouse cerebellar granule neurons were cultured for $7 \mathrm{~d}$ in depolarizing levels of $\mathrm{K}^{+}(25 \mathrm{mM})$ in the presence of serum. Simultaneous lowering of the $\mathrm{K}^{+}$concentration to $5 \mathrm{mM}$ and removal of serum $\left(\mathrm{K}^{+} /\right.$serum withdrawal) led to a loss of neuronal viability. Morphologically, most of the neurons remained normal in appearance for 2-4 hr after $\mathrm{K}^{+} /$serum withdrawal, after which they progressively underwent cytoplasmic and nuclear condensation typical of apoptosis, as has been observed previously (D’Mello et al., 1993). As assessed by the ability of the neurons to metabolize MTT, a small loss of viability was observed by $4 \mathrm{hr}$ after $\mathrm{K}^{+}$/serum withdrawal. At $8 \mathrm{hr}$ the viability was reduced to $40 \%$ of untreated control cultures, and by $24 \mathrm{hr}$ viability was reduced to $80 \%$ (Fig. $1 A$ ). Nuclear staining with Hoechst 33342 confirmed that the loss of viability was attributable to apoptosis. Nuclear condensation was observed in a small percentage of neurons as early as $2 \mathrm{hr}$ after $\mathrm{K}^{+} /$serum withdrawal. By $8 \mathrm{hr}$, the majority of the neurons contained condensed nuclei, with some showing margination of the chromatin and nuclear fragmentation (Fig. 2D). Of note, however, and in agreement with the MTT data, some of the neurons appeared to be resistant to the apoptotic stimulus, showing no evidence of nuclear condensation even at $24 \mathrm{hr}$ (data not shown). Cerebellar granule neuron apoptosis was blocked significantly by treatment with either $10 \mu \mathrm{g} / \mathrm{ml}$ cycloheximide (Figs. $1 B, 2 G$ ) or $1 \mu \mathrm{g} / \mathrm{ml}$ actinomycin D (Fig. $2 H$ ). The need for macromolecular synthesis to activate apoptosis in cerebellar granule neurons has been observed previously (D'Mello et al., 1993; Galli et al., 1995).

To induce necrotic cell death, cerebellar neurons were exposed to high concentrations of glutamate that were shown previously to induce an acute, nonapoptotic cell death (Ankarcrona et al., 1995). Thirty minutes of exposure of the neurons to $0.3-3.0 \mathrm{~mm}$ glutamate in the presence of $10 \mu \mathrm{M}$ glycine led to a loss of viability that differed both kinetically and morphologically from that induced by $\mathrm{K}^{+} /$serum deprivation. Treatment with either $300 \mu \mathrm{M}$ or $3 \mathrm{~mm}$ glutamate led to a more rapid loss of viability: at the earliest time point studied $(2 \mathrm{hr})$ after glutamate treatment, neuronal viability had reached its nadir of $20 \%$ of untreated control (Fig. $1 A$ ). Morphologically, these neurons displayed none of the typical signs of apoptosis. Most of the neurons appeared swollen or ruptured by phase-contrast microscopy, with nuclei that appeared similar to control after staining with the Hoechst dye (Fig. 2I). Exposure to fresh serum, which acutely kills cerebellar granule neurons through a glutamate-like mechanism (Schramm et al., 1990), produced similar results (data not shown). On prolonged incubation after glutamate exposure (8-24 hr), some of the nuclei appeared condensed (Fig. $2 J$ ). These may represent a population of neurons that undergo delayed apoptotic death as reported previously (Ankarcrona et al., 1995). In contrast to the apoptotic death induced by $\mathrm{K}^{+} /$serum withdrawal, glutamateinduced cell death was not inhibited significantly by either cycloheximide (Fig. $1 C$ ) or actinomycin D (data not shown). These observations are in agreement with previous reports demonstrating that exposure to high-dose glutamate leads to acute, necrotic death of cerebellar granule neurons (Ankarcrona et al., 1995).

\section{Involvement of CED3/ICE protease(s) in apoptotic granule neuron death}

Peptide inhibitors of CED3/ICE proteases have been shown to inhibit trophic factor deprivation-induced apoptosis of motoneurons (Milligan et al., 1995) and cerebellar granule neurons (Schulz et al., 1996). We tested the ability of ZVAD-fmk, a selective, irreversible inhibitor of CED3/ICE proteases, to inhibit cerebellar granule neuron apoptosis. ZVAD-fmk inhibits recombinant ICE and CPP32 proteases $\sim 10,000$-fold and 500-fold faster, respectively, than it does the cysteine protease calpain 1 and has no observable inhibitory activity against the Asp-X-directed serine protease granzyme B (Armstrong et al., 1996). ZVAD-fmk $(50 \mu \mathrm{M})$ significantly inhibited the loss of viability observed after $\mathrm{K}^{+} /$serum deprivation (Figs. $1 B$, $2 C$ ). The inhibition by ZVAD-fmk at $24 \mathrm{hr}$ was not complete, with maximal inhibition ranging from $\sim 30 \%$ to $80 \%$ in different experiments. Inhibition by ZVAD-fmk was dose-dependent (data not shown) and specific, because a control cysteine protease inhibitor, ZFA-fmk, which lacks the Asp in the P1 position, had no antiapoptotic activity (Fig. $1 B$ ). ZVAD-fmk treatment also dramatically reduced the nuclear condensation observed after $\mathrm{K}^{+}$/serum deprivation (Fig. 2D). In contrast to its anti-apoptotic effects, ZVAD-fmk failed to inhibit the necrotic death of cerebellar neurons induced by exposure to either $0.3 \mathrm{~mm}$ (Fig. $1 C$ ) or $3 \mathrm{~mm}$ glutamate (data not shown). These results demonstrate a role for CED3/ICE proteases in apoptotic, but not necrotic, death of cerebellar granule neurons.

\section{CED3/ICE family proteases are activated during cerebellar granule neuron apoptosis}

Having established a role for CED3/ICE proteases in cerebellar granule neuron apoptosis, we analyzed the process of protease activation in this model. Detergent extracts prepared from neurons at various times after $\mathrm{K}^{+}$/serum withdrawal were tested for Ac-DEVD-amc cleaving activity. Ac-DEVD-amc is a fluorogenic, tetrapeptide substrate that is cleaved by CED3/ICE proteases (Nicholson et al., 1995; Armstrong et al., 1996). By 2 hr after $\mathrm{K}^{+}$/serum withdrawal, a small increase in DEVD-amc cleavage activity was observed, and by $8 \mathrm{hr}$ protease activity had increased almost 14-fold over control extracts from untreated cells, decreasing by $24 \mathrm{hr}$ (Fig. $3 A$ ). In contrast, no increase in DEVD-amc cleaving activity was observed at any time during glutamateinduced cell death (Fig. 3A). Even as early as 15-60 min after glutamate exposure, no DEVD-amc cleaving activity was observed (data not shown). Induction of the CED3/ICE-like protease activity was prevented in neurons treated with $1 \mu \mathrm{g} / \mathrm{ml}$ actinomycin D, $10 \mu \mathrm{g} / \mathrm{ml}$ cycloheximide, or $50 \mu \mathrm{M}$ ZVAD-fmk (Fig. $3 B$ ), each of which inhibited apoptosis induced by $\mathrm{K}^{+} /$serum withdrawal (Figs. 1,2). Inhibition of DEVD-amc cleaving activity by ZVADfmk was not attributable to inhibition by residual inhibitor that was present post-lysis, because control experiments in which recombinant human CPP32 was added to cells treated with ZVADfmk before cell lysis demonstrated that residual inhibitor was not present after washing (data not shown). Thus, activation of the CED3/ICE protease activity in apoptotic granule neurons requires both macromolecular synthesis and the action of CED3/ ICE-like proteases.

The Ac-DEVD-amc cleaving activity induced after $\mathrm{K}^{+} /$serum withdrawal was inhibited by Ac-DEVD-aldehyde, a potent, reversible inhibitor of several CED3/ICE proteases (Nicholson et al., 1995; Fernandes-Alnemri et al., 1995a,b, 1996). The $\mathrm{IC}_{50}$ of Ac-DEVD-aldehyde inhibition of the protease activity from an $8 \mathrm{hr}$ apoptotic granule neuron extract was $0.65 \mathrm{nM}$, similar to that for inhibition of recombinant human CPP32 $\left(\mathrm{IC}_{50} 0.5 \mathrm{~nm}\right.$; 
A
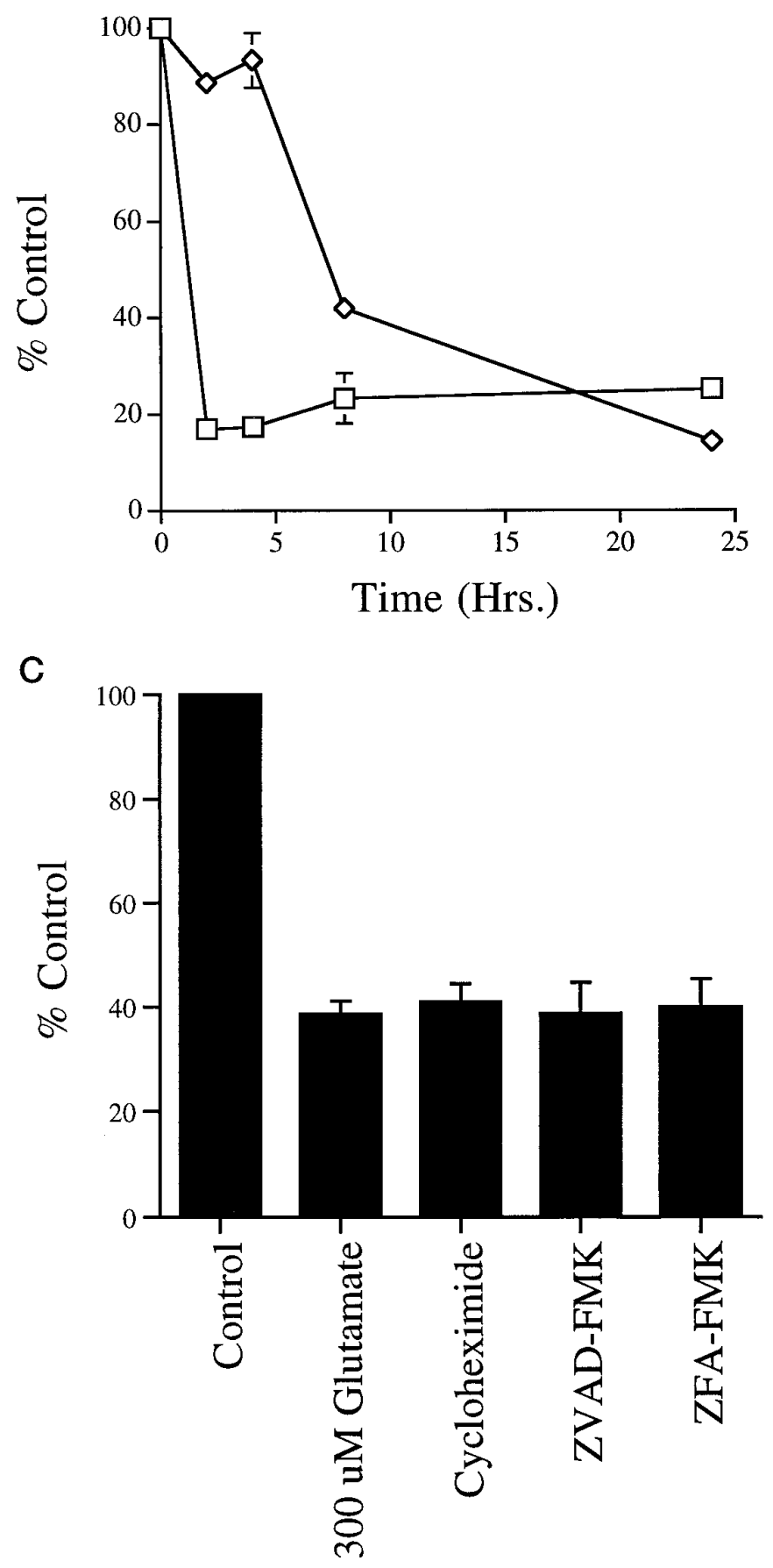

Fig. 4A). The granule neuron protease activity was also inhibited completely by an affinity-purified, function-blocking polyclonal antibody to the $C$ terminus of the mouse CPP32 p20 subunit (Fig. 4B). The anti-CPP32p20Pep specifically inhibited CPP32 protease activity, because it did not inhibit mouse ICE protease activity (Fig. $4 B$ ). The anti-CPP32p20Pep IC $_{50}$ of 217 $\mu \mathrm{g} / \mathrm{ml}$ against the granule neuron apoptotic protease activity was nearly identical to that for inhibition of recombinant human CPP32 (228 $\mu \mathrm{g} / \mathrm{ml}$; Fig. 4B). These data demonstrate that the CED3/ICE-like protease activity induced in granule neurons undergoing apoptosis is biochemically and immunologically similar to CPP32.

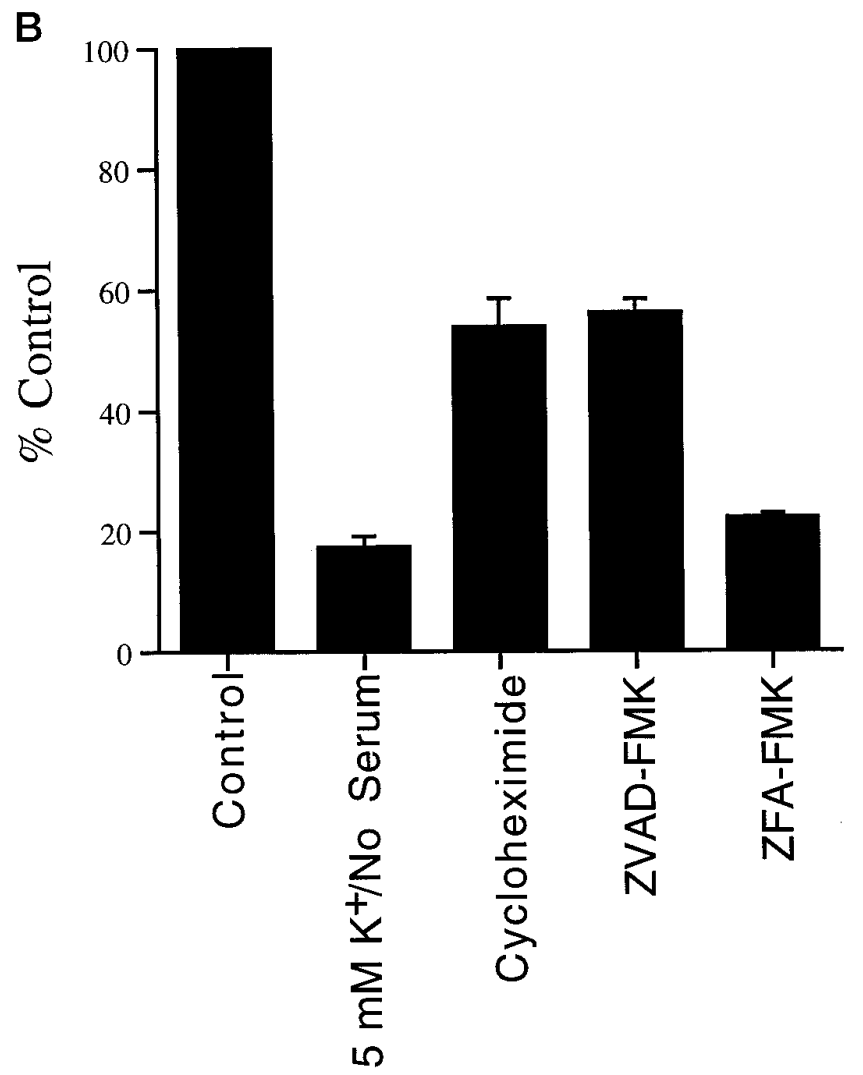

Figure 1. Cerebellar granule neuron cell death induced by withdrawal of $\mathrm{K}^{+} /$serum or exposure to glutamate. $A$, Time course of loss of viability of granule neurons after $\mathrm{K}^{+}$/serum deprivation (open diamonds) or exposure to $300 \mu \mathrm{M}$ glutamate (open squares). $B$, Viability of granule neurons $24 \mathrm{hr}$ after $\mathrm{K}^{+}$/serum deprivation $\left(5 \mathrm{~mm} \mathrm{~K} \mathrm{~K}^{+} /\right.$No Serum $)$without or with cycloheximide (Cycloheximide) $(10 \mu \mathrm{g} / \mathrm{ml})$, ZVAD-fmk $(Z V A D-F M K)(50 \mu \mathrm{M})$, or ZFAfmk $(Z F A-F M K)(50 \mu \mathrm{M})$. C , Viability of granule neurons $2 \mathrm{hr}$ after exposure to glutamate $(300 \mu \mathrm{M})$ without or with cycloheximide $(10 \mu \mathrm{g} / \mathrm{ml})$, ZVAD-fmk $(50 \mu \mathrm{M})$, or ZFA-fmk $(50 \mu \mathrm{M})$. Cell viability was measured using MTT. Values represent the mean \pm SEM of triplicate cultures run in parallel and are expressed as percentage of untreated control cultures.

\section{CPP32 is processed after $\mathrm{K}^{+}$/serum withdrawal}

CED3/ICE proteases activated during cerebellar neuron apoptosis were identified by affinity labeling with an irreversible inhibitor of ICE family proteases, ZVK (Biotin)D-fmk. ZVK(Biotin)D-fmk covalently modifies the active site cysteine of the processed "p20" subunits of several recombinant, active ICE family proteases, including human CPP32 and mouse ICE (data not shown). Untreated control or $8 \mathrm{hr}$ apoptotic extracts were incubated for $20 \mathrm{hr}$ with $0.1 \mu \mathrm{M} \mathrm{ZVK}$ (biotin)D-fmk, sufficient time to inhibit all of the Ac-DEVD-amc cleaving activity present in the apoptotic extract. Detection of covalently labeled proteins 

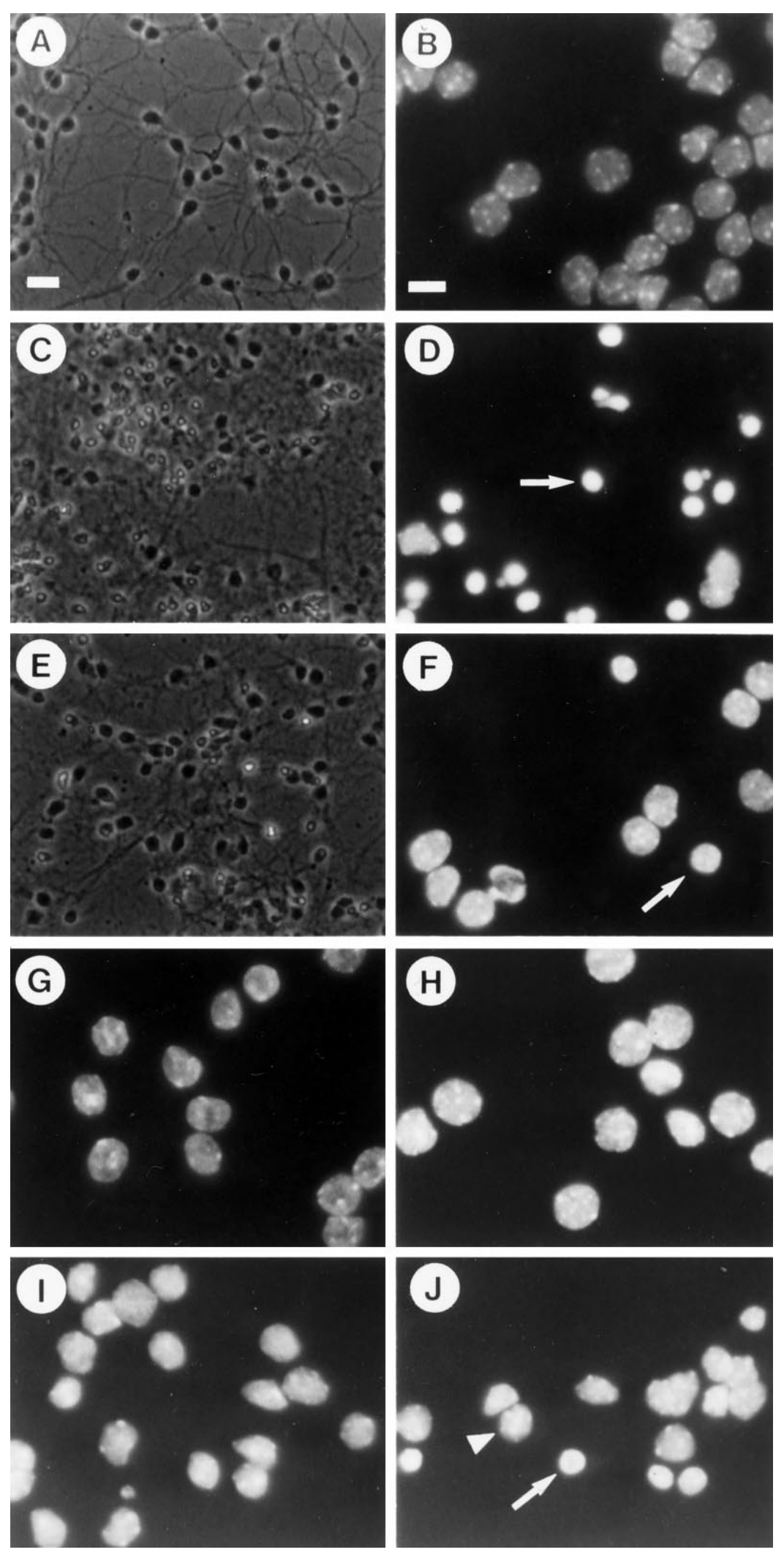

Figure 2. Phase-contrast $(A, C, E)$ and Hoechst 33342 immunofluorescence $(B, D, F-J)$ microscopy of cerebellar granule neurons after $\mathrm{K}^{+}$/serum withdrawal $(A-H)$ or exposure to 300 $\mu \mathrm{M}$ glutamate $(I, J)$. Phase-contrast of control untreated neurons $(A)$ or neurons $24 \mathrm{hr}$ after high $\mathrm{K}^{+} /$serum withdrawal in the absence $(C)$ or presence $(E)$ of $50 \mu \mathrm{M}$ ZVAD-fmk. Note highly refractile, condensed cell bodies ( $\sim 2-3 \mu \mathrm{M}$ diameter) of apoptotic neurons in $C$ and the relative reduction in their proportion in $E$. Hoechst-labeled nuclei of control, untreated granule neurons $(B)$, or neurons after $8 \mathrm{hr}$ of $\mathrm{K}^{+} /$serum withdrawal in the absence $(D)$ or presence $(F)$ of $50 \mu \mathrm{M} \mathrm{ZVAD-fmk.} \mathrm{Arrow} \mathrm{in} D$ marks a highly condensed, apoptotic nucleus. Arrow in $F$ marks a nucleus that is less well protected by ZVAD-fmk than the surrounding nuclei. Hoechst-labeled nuclei of cells $24 \mathrm{hr}$ after $\mathrm{K}^{+} /$serum withdrawal in the presence of either $10 \mu \mathrm{g} / \mathrm{ml}$ cycloheximide $(G)$ or $1 \mu \mathrm{g} / \mathrm{ml}$ actinomycin D $(H)$. Note normal size and morphology of nuclei in $G$ and $H$. Hoechst-labeled nuclei in cells $2(I)$ or $8 \mathrm{hr}(J)$ after exposure to $300 \mu \mathrm{M}$ glutamate. Note that nuclei in $I$ look normal in size and appearance of nucleoli. Arrow in $J$ marks a nucleus that appears slightly shrunken compared with the normal-sized nucleus indicated by the arrowhead. Scale bars: $A, 25 \mu \mathrm{M} ; B, 10 \mu \mathrm{M}$. by Western blotting using streptavidin/alkaline phosphatase identified two protease subunits of $\sim 20$ and $18 \mathrm{kDa}$ present only in the apoptotic extracts (Fig. 5A). Western blotting of the apoptotic extracts with antibodies to the $\mathrm{C}$ terminus of the large subunit of CPP32 identified two proteins, p20 and p18, that co-migrated with those recognized by the affinity label (Fig. $5 B$ ). The p20 protein co-migrated with recombinant mouse CPP32 p20 expressed in bacteria (Fig. $5 B$ ). The same two immunoreactive bands were observed with two additional independently derived CPP32 p20 antisera (Fig. $5 B$ and data not shown). Neither of the CPP32 
A

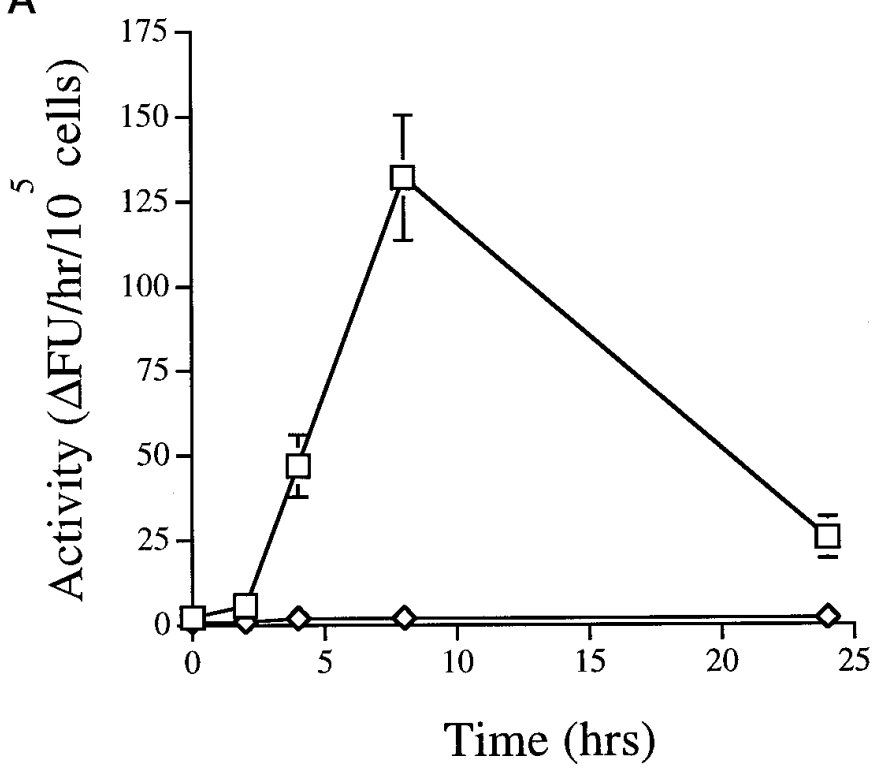

B

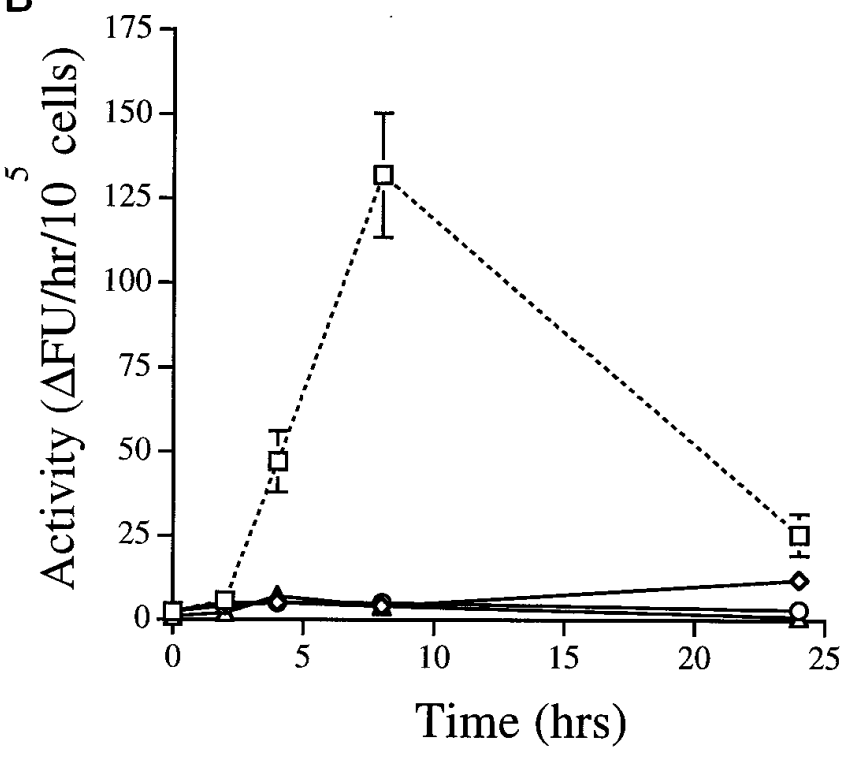

Figure 3. Induction of a Ac-DEVD-amc cleaving protease activity after $\mathrm{K}^{+} /$serum deprivation but not after exposure to glutamate. $A$, Time course of induction of Ac-DEVD-amc cleaving activity in extracts of granule neurons after $\mathrm{K}^{+} /$serum withdrawal (open squares) or exposure to 3 mM glutamate (open diamonds). B. Time course of induction of Ac-DEVD-amc cleaving activity in extracts of granule neurons after $\mathrm{K}^{+} /$serum deprivation in the absence (open squares with dotted line; data replotted from $A)$ or in the presence of cycloheximide $(10 \mu \mathrm{g} / \mathrm{ml}$; open diamonds), actinomycin D (1 $\mu \mathrm{g} / \mathrm{ml}$; open circles $)$, or ZVAD-fmk $(50 \mu \mathrm{M}$; open triangle $)$. Values represent the mean \pm SEM of triplicate reactions run in parallel and are expressed as the change in fluorescence units per hour per $10^{5}$ cells.

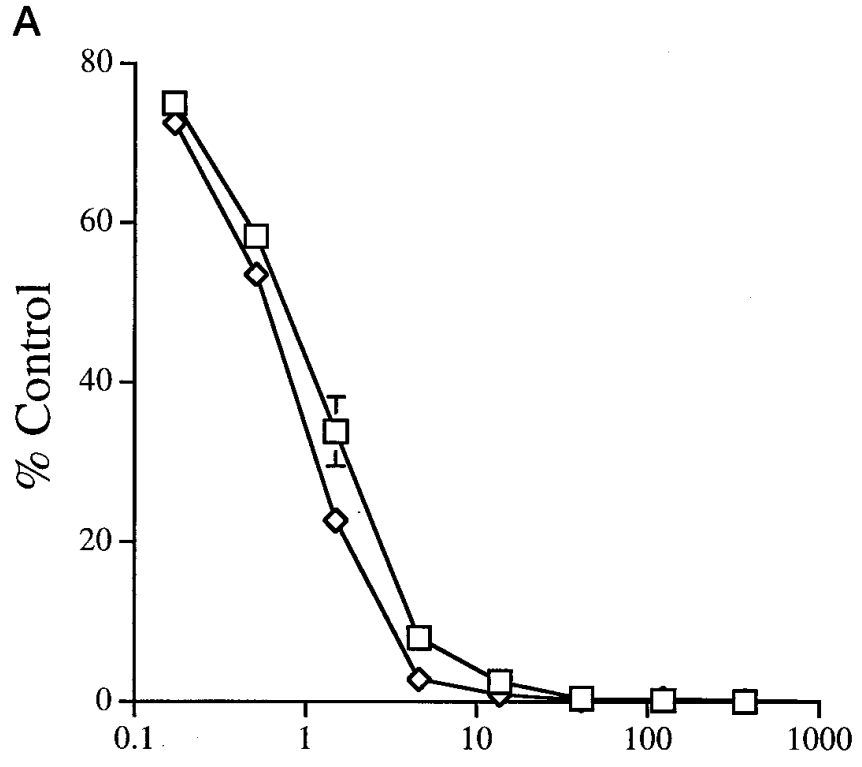

Concentration (nM)
B

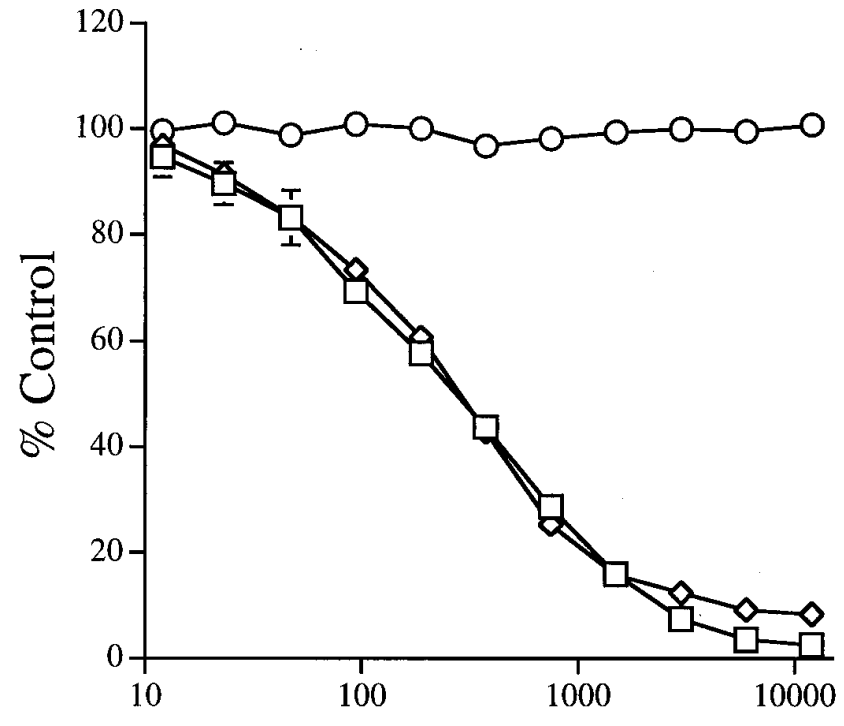

Figure 4. Inhibition by Ac-DEVD-aldehyde $(A)$ and affinity-purified anti-CPP32 p20 $(B)$ of the Ac-DEVD-amc cleaving activity present in extracts of granule neurons $8 \mathrm{hr}$ after $\mathrm{K}^{+} /$serum deprivation. $A$, Dose-response of inhibition by Ac-DEVD-aldehyde of granule neuron protease activity (open squares) or recombinant human CPP32 protease (open diamonds). B, Dose-response of inhibition by anti-CPP32p20Pep of granule neuron protease activity (open squares), recombinant human CPP32 protease (open diamonds), or recombinant mouse ICE protease (open circles). Values represent the mean \pm SEM of triplicate reactions run in parallel and are expressed as percentage of activity in uninhibited, control reactions.

immunoreactive proteins was detected in extracts prepared from cells treated with glutamate for either 2 or $8 \mathrm{hr}$ (Fig. 5B). Thus, CPP32 is processed proteolytically to produce p20 and p18 subunits during cerebellar granule neuron apoptosis but not during necrosis. Incubation of cells with ZVAD-fmk prevented processing of pro-CPP32 to p20 and p18 subunits (Fig. 5B). Thus, CPP32 processing is inhibited by a selective inhibitor of CED3/ICE family proteases. 
A

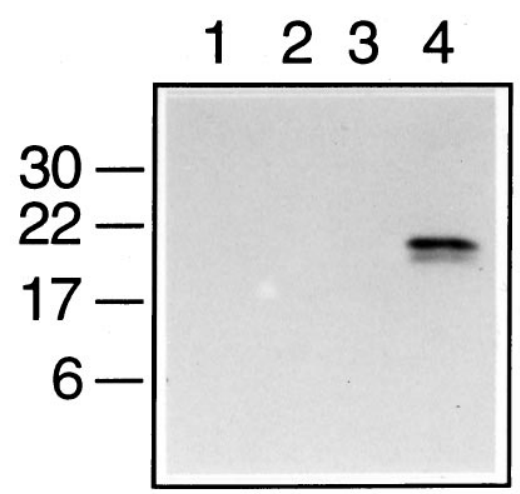

B
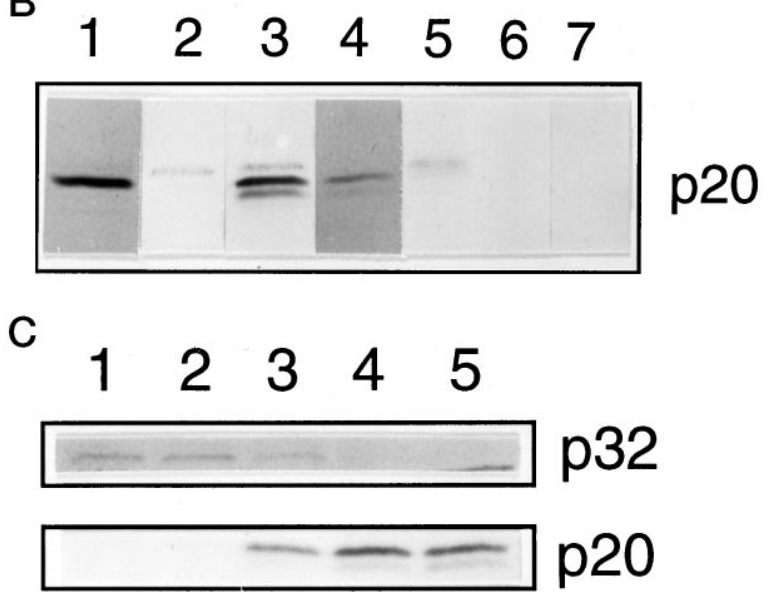

Figure 5. The CPP32 proenzyme is cleaved to generate p20/p18 subunits. $A$, Affinity labeling with $\mathrm{ZVK}$ (biotin)D-fmk of protease subunits in extracts of granule neurons before (lanes 1 and 2) or $8 \mathrm{hr}$ after (lanes 3 and 4) $\mathrm{K}^{+} /$serum withdrawal either in the presence (lanes 2 and 4 ) or absence (lanes 1 and 3) of ZVK(biotin)D-fmk. Two proteins of $M_{\mathrm{r}} 20$ and $18 \mathrm{kDa}$ are labeled in the $8 \mathrm{hr}$ apoptotic extract. $B$, Western blotting with affinitypurified anti-CPP32p20Pep (lanes 1-3, 5-7) or with the anti-CPP32RP antiserum (lane 4). Lane 1: recombinant mouse CPP32; lane 2: extracts of unstimulated granule neurons; lanes 3 and 4: extracts of granule neurons $8 \mathrm{hr}$ after $\mathrm{K}^{+} /$serum deprivation; lane 5: extracts of granule neurons $8 \mathrm{hr}$ after $\mathrm{K}^{+}$/serum deprivation in the presence of $50 \mu \mathrm{M} \mathrm{ZVAD}$-fmk; lanes 6 and 7: extracts of granule neurons $2 \mathrm{hr}$ (lane 6) or $8 \mathrm{hr}$ (lane 7) after exposure to $300 \mu \mathrm{M}$ glutamate. $C$, Time course of disappearance of $\mathrm{p} 32$ proenzyme and appearance of p20 subunits before (lane 1) and at $2 \mathrm{hr}$ (lane 2), $4 \mathrm{hr}$ (lane 3), $6 \mathrm{hr}$ (lane 4), and $8 \mathrm{hr}$ (lane 5) after $\mathrm{K}^{+} /$serum withdrawal. Top panel was blotted with the anti-CPP32RP antiserum; bottom panel was blotted with the affinity-purified anti-CPP32p20Pep.

A time course study in apoptotic neurons revealed that the 32 $\mathrm{kDa}$ CPP32 proenzyme was expressed in unstimulated cells and was processed proteolytically within the first $8 \mathrm{hr}$ of apoptosis. The anti-CPP32RP recognized the p32 proenzyme form of CPP32 in resting, unstimulated extracts, the levels of which declined substantially by $8 \mathrm{hr}$ (Fig. 5C). Coincident with the disappearance of the CPP32 proenzyme, the processed p20 and p18 subunits recognized by anti-CPP32p20Pep accumulated (Fig. 5C).

\section{DISCUSSION}

This study demonstrates for the first time the proteolytic processing and activation of a CED3/ICE protease, CPP32, in a model of neuronal apoptosis: $\mathrm{K}^{+}$/serum deprivation-induced cerebellar granule neuron apoptosis. By enzymological and biochemical criteria, CPP32 was proteolytically cleaved and activated early dur- ing apoptosis. CPP32 activation was not observed when apoptosis was inhibited by treatment with a selective inhibitor of CED3/ICE proteases or with inhibitors of RNA or protein synthesis. CPP32 activation was also not observed when the neurons were induced to die by necrosis after exposure to high levels of glutamate. Thus, CPP32 activation is an early biochemical marker of apoptosis in this neuronal cell type.

The CPP32 protease is processed and activated in neurons undergoing apoptosis but not during necrosis. CPP32 activation may thus be a useful marker for distinguishing apoptotic neurons from necrotic neurons in vitro and in vivo during neural development and after pathological brain insult. To compare CPP32 activation in apoptosis and necrosis, we chose two well characterized in vitro cerebellar granule neuron cell death models. Cultured neonatal rodent cerebellar granule neurons grown for $7 \mathrm{~d}$ under depolarizing conditions in high $(25 \mathrm{~mm})$ potassium undergo classical apoptotic changes on simultaneous lowering of potassium (to $5 \mathrm{~mm}$ ) and serum withdrawal (D'Mello et al., 1993; Yan et al., 1994). These changes include cell shrinkage, nuclear condensation and fragmentation, and DNA cleavage into oligonucleosomalsized fragments (D’Mello et al., 1993). Cerebellar granule apoptosis, like trophic factor deprivation-induced apoptosis (Deckwerth and Johnson, 1993; Milligan et al., 1994, 1995), is blocked by inhibitors of macromolecular synthesis (D'Mello et al., 1993; Galli et al., 1995) (Fig. 2). The apoptotic death of granule neurons observed using our culture conditions recapitulated the apoptotic changes observed previously by others (Figs. 1, 2). In contrast, granule neurons exposed to fresh serum or to high concentrations (0.3-3.0 mM) of glutamate undergo a more rapid, nonapoptotic form of cell death in which there is little cell shrinkage, the nuclei remain intact, and nuclear DNA is cleaved neither to the large (50-300 kb) nor the small oligonucleosomal fragments normally observed during apoptosis (Ankarcrona et al., 1995) (Fig. 2). In addition to the kinetic and morphological differences, these two forms of cerebellar granule neuron cell death are distinguished biochemically by the presence or absence of endonuclease activity (Ankarcrona et al., 1995) and by their sensitivity to inhibition by (1) inhibitors of macromolecular synthesis (D'Mello et al., 1993) (Figs. 1, 2) and (2) a selective inhibitor of CED3/ICE proteases, ZVAD-fmk (Figs. 1, 2). Our inability to detect either Ac-DEVDamc cleaving activity or CPP32 processing after acute glutamateinduced necrosis further distinguishes granule neuron apoptosis from necrosis biochemically and suggests a selective role for the CPP32 protease in granule neuron apoptosis.

Ankarcrona et al. (1995) showed previously that after the acute, necrotic death of cerebellar granule neurons exposed to $300 \mu \mathrm{M}$ or $3 \mathrm{~mm}$ glutamate, the remaining neurons undergo a delayed, apoptotic death beginning at $\sim 8-12 \mathrm{hr}$. Although our study was not designed to examine this delayed form of apoptosis, it is interesting that we failed to detect CPP32 activation as late as $24 \mathrm{hr}$ after exposure to glutamate. There are several possible explanations for this. First, the amount of CPP32 activated in the remaining neurons after the acute phase of necrotic cell death may be below the limits of detection of our biochemical assays. Alternatively, CPP32 may not be activated in delayed glutamate-induced apoptosis in these neurons. Experiments are in progress to examine these and other possibilities.

Our studies demonstrate clearly that the CPP32 proenzyme is cleaved from its $32 \mathrm{kDa}$ precursor form to an active form as early as $4 \mathrm{hr}$ after induction of apoptosis. CPP32 enzymatic activity (defined as anti-CPP32 inhibitable, Ac-DEVD-amc cleaving activity) was elevated $>10$-fold within $8 \mathrm{hr}$ of the apoptotic stimulus. 
Pro-CPP32, like all members of the CED3/ICE family, is cleaved at Asp-X peptide bonds to generate an active protease containing a large $(\sim 20 \mathrm{kDa})$ and a small $(\sim 12 \mathrm{kDa})$ subunit (Nicholson et al., 1995). Our antibodies to the $C$ terminus of the large subunit of mouse CPP32 (anti-CPP32p20Pep) recognized two proteins of 20 and $18 \mathrm{kDa}$, one of which co-migrated with the large subunit of active, recombinant mouse CPP32. As expected for processed large subunits of active CPP32, the p20 and p18 proteins accumulated coincidentally with the increase in Ac-DEVD-amc cleaving activity and were specifically labeled with an irreversible CED3/ ICE inhibitor that covalently modifies the active site cysteine contained in the large subunits of active CPP32 and other ICE proteases. Based on the ability of three different anti-CPP32 p20 antisera to recognize both p20 and p18 proteins, we believe it to be likely that both immunoreactive proteins are subunits of active mouse CPP32; however, we cannot exclude the possibility that the CPP32 antibodies used also recognize closely related homologs of mouse CPP32. Biochemical (Nicholson et al., 1995) and sitedirected mutagenesis (Fernandes-Alnemri et al., 1996) studies of human CPP32 indicate that in addition to the cleavage site between the large and small subunits (Asp 175), pro-CPP32 is processed proteolytically at two sites (Asp9 and Asp28) in the $\mathrm{N}$ terminus of the p20 subunit. Comparison of the cleavage sites in human and mouse CPP32 show that although the Asp 9 cleavage site is relatively well conserved (NSVD vs TSVD), the Asp 28 cleavage site has a charge reversal in the P4 position (ESMD vs KSVD) that could decrease processing at Asp 28. Although we have not yet sequenced the CPP32 p20 and p18 immunoreactive proteins, we consider it likely that the p20 and p18 proteins represent large subunits of CPP32 that are differentially processed at their amino termini.

The consequences of CPP32 activation in cerebellar granule neurons are unknown. CPP32 has been implicated in the cleavage of several proteins that function in cellular metabolism and homeostasis, including poly-(ADP-ribose)-polymerase (PARP), a nuclear protein involved in DNA repair that is cleaved in many models of apoptosis (Nicholson et al., 1995; Tewari et al., 1995; Armstrong et al., 1996). It seems likely that PARP is also cleaved during neuronal apoptosis. Unfortunately, our attempts to detect PARP cleavage in the cerebellar granule neurons were unsuccessful because of the species-specificity of the PARP monoclonal antibody that we used (R. Armstrong, unpublished observations). A recent study (Schulz et al., 1996) showed that the production of reactive oxygen species in cerebellar granule neurons undergoing apoptosis is downstream of the activation of an unidentified CED3/ICE protease activity. Our data, together with those of Schulz et al. (1996), suggest that CPP32 may lie on a pathway leading to production of reactive oxygen species.

The mechanism by which the CPP32 protease becomes activated is unknown but does not seem to require de novo CPP32 expression. Western blot data (Fig. 5) indicate that the CPP32 proenzyme is expressed in resting, unstimulated cultures. Inhibitors of macromolecular synthesis, however, do prevent apoptosis and the proteolytic processing and activation of CPP32, indicating that the transcription/translation-dependent step in cerebellar granule apoptosis is upstream of CPP32 activation (also see Schulz et al., 1996). One possible site of action of these gene products is regulation of the protease(s) that cleave pro-CPP32. ZVAD-fmk blocked CPP32 processing, indicating that a protease(s) with substrate specificity similar to CPP32 cleaves proCPP32. This could be either active CPP32 itself or an upstreamactivated CED3/ICE protease (Fernandes-Alnemri et al., 1996;
Liu et al., 1996; Orth et al., 1996). The expression or function of this unidentified protease could be modified in a transcription- or translation-dependent manner. Neuronal apoptosis requires new gene expression in a number of model systems in vitro (Deckwerth and Johnson, 1993; Milligan et al., 1994) and in vivo (Oppenheim et al., 1990; Linnik et al., 1993). For example, c-Jun is upregulated early and is required for neurotrophin withdrawal-induced apoptosis in sympathetic neurons (Estus et al., 1994; Ham et al., 1995). Our data suggest a model in which components of the cell death effector machinery, including CPP32, are already expressed in neuronal cells, and their activity is regulated, directly or indirectly, by factors that require new gene expression to exert their action(s). Recent studies demonstrating that staurosporin induces apoptosis in many cell types, including postmitotic cardiac myocytes, in the absence of new protein synthesis (Weil et al., 1996) is consistent with this view.

In summary, we have shown that the CED3/ICE protease CPP32 is processed and activated in cerebellar granule neurons undergoing apoptosis but not necrosis. CPP32 activation requires continued macromolecular synthesis and CED3/ICE protease activity. Although these data indicate a role for CPP32 in the effector pathway of neuronal apoptosis, whether the CPP32 protease plays a necessary role will require inhibition of $\mathrm{CPP} 32$ with selective protease inhibitors. Although initially described as a CPP32-selective inhibitor (Nicholson et al., 1995), the tetrapeptide Ac-DEVD-aldehyde inhibits several members of the CED3-ICE protease family nearly as potently as CPP32 (Fernandes-Alnemri et al., 1995b; 1996). In the absence of selective protease inhibitors, the role of CPP32 in neuronal apoptosis could be examined through inducible, targeted inactivation of the CPP32 gene.

\section{REFERENCES}

Allsopp TE, Wyatt S, Patterson HF, Davies AM (1993) The protooncogene bcl-2 can selectively rescue neurotrophic factor dependent neurons from apoptosis. Neuron 7:295-307.

Ankarcrona M, Dypbukt JM, Bonfoco E, Zhivotovsky B, Orrenius S, Lipton SA, Nicotera P (1995) Glutamate-induced neuronal death: a succession of necrosis or apoptosis depending on mitochondrial function. Neuron 15:961-973.

Armstrong RC, Aja T, Xiang J, Gaur S, Krebs JF, Hoang K, Bai X, Korsmeyer SJ, Karanewsky DS, Fritz LC, Tomaselli KJ (1996) Fasinduced activation of the cell death related protease CPP32 is inhibited by $\mathrm{Bcl}-2$ and by ICE family protease inhibitors. $\mathrm{J}$ Cell Biol 271:16850-16855.

Bertin J, Mendrysa SM, LaCount DJ, Gaur S, Krebs J, Armstrong RC, Tomaselli KJ, Friesen PD (1996) Apoptotic suppression by baculovirus p35 involves cleavage by and inhibition of a virus-induced CED3/ ICE-like protease. J Virol 70:6251-6259.

Blaschke AJ, Staley K, Chun J (1996) Widespread programmed cell death in proliferative and postmitotic regions of the fetal cerebral cortex. Development 122:1165-1174.

Boldin MP, Goncharov TM, Goltsev YV, Wallach D (1996) Involvement of MACH, a novel MORT1/FADD-interacting protease, in Fas/ AP0-1- and TNF receptor-induced cell death. Cell 85:803-815.

Bredesen DE (1995) Neural apoptosis. Ann Neurol 38:839-851.

Bump NJ, Hackett M, Hugunin M, Seshagiri S, Brady K, Chen P, Ferenz C, Franklin S, Ghayur T, Li P, Licari P, Mankovich J, Shi L, Greenberg AH, Miller LK, Wong WW (1995) Inhibition of ICE family proteases by baculovirus antiapoptotic protein p35. Science 269:1885-1888.

Cerretti DP, Kozlosky C, Mosley B, Nelson N, Van Ness K, Greenstreet TA, March CJ, Kronheim SR, Druck T, Cannizzaro LA, Huebner K, Black RA (1992) Molecular cloning of the interleukin-1 $\beta$ Caenorhabditis elegans cell death protein Ced-3 and mammalian interleukin-1 $\beta$ crmA gene. Science 263:826-828.

Chinnaiyan AM, Orth K, O'Rourke K, Duan H, Poirier GG, Dixit VM (1996) Molecular ordering of the cell death pathway. J Biol Chem 271:4573-4576.

Darmon AJ, Ehrman N, Caputo A, Fujinaga J, Bleackley RC (1995) 
Activation of the apoptotic protease CPP32 by cytotoxic T-cell-derived granzyme B. Nature 377:446-448.

Deckwerth TL, Johnson EM (1993) Temporal analysis of events associated with programmed cell death (apoptosis) of sympathetic neurons deprived of nerve growth factor. J Cell Biol 123:1207-1222.

D'Mello SR, Galli C, Ciotti T, Calissano P (1993) Induction of apoptosis in cerebellar granule neurons by low potassium: inhibition of death by insulin-like growth factor I and cAMP. Proc Natl Acad Sci USA 90:10989-10993.

Duan H, Orth K, Chinnaiyan AM, Poirier GG, Froelich CJ, He W-W, Dixit VM (1996) ICE- LAP6, a novel member of the ICE/Ced-3 gene family, is activated by the cytotoxic T cell protease granzyme B. J Biol Chem 271:16720-16724.

Estus S, Zaks WJ, Freeman RS, Gruda M, Bravo R, Johnson EM (1994) Altered gene expression in neurons during programmed cell death indentification of c-jun as necessary for neuronal apoptosis. J Cell Biol 127:1717-1727.

Faucheu C, Diu A, Chan AW, Blanchet AM, Miossec C, Herve F, Collard-Dutilleul V, Gu Y, Aldape RA, Lippke JA, Rocher C, Su U, Livingston DJ, Hercend T, Lalanne JL (1995) A novel human protease similar to the interleukin- $1 \beta$ converting enzyme induces apoptosis in transfected cells. EMBO J 14:1914-1922.

Fernandes-Alnemri T, Litwack G, Alnemri E (1994) CPP32, a novel apoptotic protein with homology to Caenorhabditis elegans cell death protein Ced-3 and mammalian interleukin- $1 \beta$-converting enzyme. J Biol Chem 269:30761-30764.

Fernandes-Alnermi T, Litwack G, Alnemri ES (1995a) Mch-2, a new member of the apoptotic Ced-3/ICE cysteine protease gene family. Cancer Res 55:2737-2742

Fernandes-Alnemri T, Takahashi A, Armstrong R, Krebs J, Fritz L, Tomaselli KJ, Wang L, Yu Z, Croce C, Salvesen G, Earnshaw WC, Litwack G, Alnemri ES (1995b) Mch3, a novel human apoptotic cysteine protease highly related to CPP32. Cancer Res 55:6045-6052.

Fernandes-Alnemri T, Armstrong RC, Krebs JF, Srinivasula SM, Wang L, Bullrich F, Fritz LC, Trapani JA, Tomaselli KJ, Litwach G, Alnemri ES (1996) In vitro activation of CPP32 and Mch3 by Mch4, a novel human apoptotic cysteine protease containing two FADD-like domains. Proc Natl Acad Sci USA 93:7464-7469.

Gagliardini V, Fernandez PA, Lee RKK, Drexler HCA, Rotello RJ, Fishman MC, Yuan J (1994) Prevention of vertebrate neuronal death by the crmA gene. Science 263:826-828.

Galli C, Meucci O, Scorziella A, Werge T, Calissano P, Schettini G (1995) Apoptosis in cerebellar granule cells is blocked by high $\mathrm{KCl}$, forskolin and IGF-1 through distinct mechanisms of action: the involvement of intracellular calcium and RNA synthesis. J Neurosci 15:1172-1179.

Ham J, Babij C, Whitfield J, Pfarr CM, Lallemand D, Yaniv M, Rubin LL (1995) A c-Jun dominant negative mutant protects sympathetic neurons against programmed cell death. Neuron 14:927-939.

Hugunin M, Quintal LJ, Mankovich JA, Ghayur T (1996) Protease activity of in vitro transcribed and translated Caenorhabditis elegans cell death gene (ced-3) product. J Biol Chem 271:3517-3522.

Kamens J, Paskind M, Hugunin M, Talanian RV, Allen H, Banach D, Bump N, Hackett M, Johnston CG, Li P, Mankovich JA, Terranova M, Ghayur T (1995) Identification and characterization of ICH-2, a novel member of the interleukin- $1 \beta$ Nedd 2 gene, which encodes a protein similar to the product of the Caenorhabditis elegans cell death gene ced-3 and the mammalian IL- $1_{\text {relII }}$ and ICErelIII, members of the ICE/CED-3 family of cysteine proteases. J Biol Chem 270:15870-15876.

Komiyama T, Ray CA, Pickup DJ, Howard AD, Thornberry NA, Peterson EP, Salvesen G (1994) Inhibition of interleukin-1 $\beta$ converting enzyme by the cowpox virus serpin CrmA. J Biol Chem 269:19331-19337.

Kumar S, Kinoshita M, Noda M, Copeland N, Jenkins NA (1993) Induction of apoptosis by the mouse Nedd 2 gene, which encodes a protein similar to the product of the Caenorhabditis elegans cell death gene ced-3 and the mammalian IL- $1 \beta$-converting enzyme. Genes Dev 8:1613-1626.

Linnik MD, Zobrist RH, Hartfield MD (1993) Evidence supporting a role for programmed cell death in focal cerebral ischemia in rats. Stroke 24:2002-2009.

Liu X, Kim CN, Pohl J, Wang X (1996) Purification and characterization of an interleukin- $1 \beta$ converting enzyme family protease that activates cysteine protease p32 (CPP32). J Biol Chem 271:13371-13376.

Martin DP, Schmidt RE, DiStefano PS, Lowry OH, Carter JG,
Johnson EM (1988) Inhibitors of protein synthesis and RNA synthesis prevent neuronal death caused by nerve growth factor deprivation. J Cell Biol 106:829-844.

Martinou J-C, Duboies-Dauphin M, Staple JK, Rodrigez I, Frankowski H, Missotten M, Albertini P, Talabot D, Catsicas S, Pietra C, Huarte J (1994) Overexpression of BCL-2 in transgenic mice protects neurons from naturally occurring cell death and experimental ischemia. Neuron 13:1017-1030.

Milligan CE, Oppenheim RW, Schwartz LM (1994) Moto-neurons deprived of trophic support in vitro require new gene expression to undergo programmed cell death. J Neurobiol 25:1005-1016.

Milligan CE, Prevette D, Yaginuma H, Homma S, Cardwell C, Fritz LC, Tomaselli KJ, Oppenheim RW, Schwartz LM (1995) Peptide inhibitors of the ICE protease family arrest programmed cell death of motoneurons in vivo and in vitro. Neuron 15:385-393.

Munday NA, Vaillancourt JP, Ali A, Casano FJ, Miller DK, Molineaux SM, Yamin TT, Yu VL, Nicholson DW (1995) Molecular cloning and pro-apoptotic activity of $\mathrm{ICE}_{\mathrm{rel}} \mathrm{II}$ and $\mathrm{ICE}_{\mathrm{rel}} \mathrm{III}$, members of the ICE/ CED-3 family of cysteine proteases. J Biol Chem 270:15870-15876.

Muzio M, Chinnaiyan AM, Kischkel FC, O’Rourke K, Shevchenko A, Ni J, Scaffidi C, Bretz JD, Zhang M, Gentz R, Mann M, Krammer PH, Peter ME, Dixit VM (1996) FLICE, a novel FADD-homologous ICE/ CED-3-like protease, is recruited to the CD95 (Fas/APO-1) deathinducing signaling complex. Cell 85:817-827.

Nicholson DW, Ali A, Thornberry NA, Vaillancourt JP, Ding CK, Gallant M, Gareau Y, Griffin PR, Labelle M, Lazebnik YA, Munday NA, Raja SM, Smulson ME, Yamin T-T, Yu VL, Miller DK (1995) Identification and inhibition of the ICE/CED-3 protease necessary for mammalian apoptosis. Nature 376:37-43.

Oppenheim RW (1991) Cell death during the development of the nervous system. Annu Rev Neurosci 14:453-501.

Oppenheim RW, Prevette D, Tytell M, Homma S (1990) Naturally occurring and induced neuronal death in the chick embryo in vivo requires protein and RNA synthesis: evidence for the role of cell death genes. Dev Biol 138:104-113.

Orth K, O'Rourke K, Salvesen GS, Dixit VM (1996) Molecular ordering of apoptotic mammalian CED3/ICE-like proteases. J Biol Chem 271:20977-20980.

Rabizabeh S, LaCount DJ, Friesen PD, Bredesen DE (1993) Expression of the baculovirus p35 gene inhibits mammalian neural cell death J Neurochem 61:2318-2321.

Raff MC, Barres BA, Burne JF, Coles HS, Ishizaki Y, Jacobson MD (1993) Programmed cell death and the control of cell survival: lessons from the nervous system. Science 262:695-700.

Ray CA, Black RA, Kronheim SR, Greenstreet TA, Sleath PR, Salvesen GS, Pickup DJ (1992) Viral inhibition of inflammation: cowpox virus encodes an inhibitor of the interleukin- $1 \beta$ Ich-1, an Ice/ced-3-related gene, encodes both positive and negative regulators of programmed cell death. Cell 78:739-750.

Revesz L, Briswalter C, Heng R, Leutwiler A, Mueller R, Waethrich H-J (1994) Synthesis of P1 aspartate-based peptide cyloxymethyl and fluoromethyl ketones as inhibitors of interleukin-1 $\beta$-converting enzyme. Tetra Lett 35:9693-9696.

Schlegel J, Peters I, Orrenius S, Miller DK, Thornberry NA, Yamin T-T, Nicholson DW (1996) CPP32/Apopain is a key interleukin $1 \beta$ converting enzyme-like protease involved in Fas-mediated apoptosis. J Biol Chem 271:1841-1844.

Schramm M, Eimerl S, Costa E (1990) Serum and depolarizing agents cause acute neurotoxicity in cultured cerebellar granule cells: role of the glutamate receptor responsive to $N$-methyl-D-aspartate. Proc Natl Acad Sci USA 87:1193-1197.

Schulz JB, Weller M, Klockgether T (1996) Potassium deprivationinduced apoptosis of cerebellar granule neurons: a sequential requirement for new mRNA and protein synthesis, ICE-like protease activity, and reactive oxygen species. J Neurosci 16:4696-4706.

Srinivasula SM, Fernandes-Alnemri T, Zangrilli J, Robertson N, Armstrong RC, Wang L, Trapani JA, Tomaselli KJ, Litwack G, Alnemri ES (1996) The Ced-3/ICE-like homolog Mch6 and the lamin cleaving enzyme Mch $2 \alpha$ are substrates for the apoptotic mediator CPP32. J Biol Chem 271:27099-27103.

Tewari M, Quan LG, O'Rourke K, Desnoyers S, Zeng Z, Beidler DR, Poirier GG, Salvesen GS, Dixit VM (1995) Yama/CPP32B, a mammalian homolog of CED-3, is a crmA-inhibitable protease that cleaves the death substrate poly(ADP-ribose) polymerase. Cell 81:801-809.

Thornberry NA, Bull HD, Calaycay JR, Chapman KT, Howard AD, 
Kostura MJ, Miller DK, Molineaux SM, Weidner JR, Aunins J, Ellison KO, Ayala JM, Casano FJ, Chin J, Ding GJ-F, Egger LA, Gaffney EP, Limjuco G, Palyha OC, Raju SM, Rolando AM, Salley JP, Yamin T-T, Lee TD, Shively JE, MacCross M, Mumford RA, Schmidt JA, Tocci MJ (1992) A novel heterodimeric cysteine protease is required for interleukin- $1 \beta$ processing in monocytes. Nature 396:768-774.

Wang L, Miura M, Bergerson L, Zhu H, Yuan J (1994) Ich-1, an Ice/ ced-3-related gene, encodes both positive and negative regulators of programmed cell death. Cell 78:739-750.

Weil M, Jacobson MD, Coles HSR, Davies TJ, Gardner RL, Raff KD, Raff MC (1996) Constitutive expression of the machinery for programmed cell death. The Rockefeller University Press 133:1053-1059.

Wood KA, Dipasquale B, Youle RJ (1993) In situ labeling of granule cells for apoptosis associated DNA fragmentation reveals different mechanisms of cell loss in developing cerebellum. Neuron 11:621-632.

Xue D, Horvitz HR (1995) Inhibition of the Caenorhabditis elegans celldeath protease CED-3 by a CED-3 cleavage site in baculovirus p35 protein. Nature 377:248-251.

Xue D, Shaham S, Horvitz HR (1996) The Caenorhabditis elegans celldeath protein CED-3 is a cysteine protease with substrate specificities similar to those of the human CPP32 protease. Genes Dev 10:1073-1083.

Yan GM, Ni B, Weller M, Wood K, Paul SM (1994) Depolarization or glutamate receptor activation blocks apoptotic cell death of cultured cerebellar granule neurons. Brain Res 656:43-51.

Yuan J, Shaham S, Ledoux S, Ellis H, Horvitz HR (1993) The C. elegans cell death gene ced-3 encodes a protein similar to mammalian interleukin-1 $\beta$-converting enzyme. Cell 75:641-652. 